Pamiętnik Literacki 2015, 1, s. 147-167
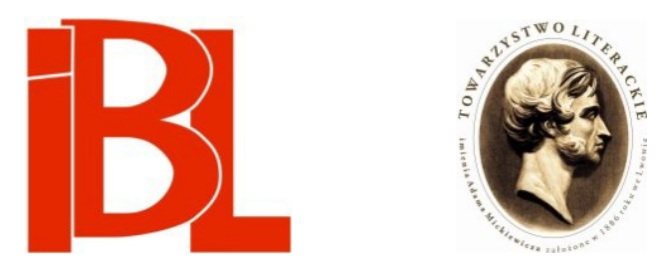

Oracje sejmowe z czasów Jana Kazimierza na rozdrożu stylistycznym (na przykładzie wotum Krzysztofa Grzymułtowskiego z 1665 roku)

Krystyna Płachcińska 


\section{ORACJE SEJMOWE Z CZASÓW JANA KAZIMIERZA NA ROZDROŻU STYLISTYCZNYM (NA PRZYKŁADZIE WOTUM KRZYSZTOFA GRZYMUL- TOWSKIEGO Z 1665 ROKU)}

Przekonanie o „Zwrocie barokowym” w rozwoju wymowy jest w nauce od dawna dobrze ugruntowane ${ }^{1}$. Także ogląd oratorstwa sejmowego potwierdza, że kultura retoryczna szlachty polskiej w drugiej połowie XVII stulecia była w ogromnej mierze odmienna od tej z czasów „złotego wieku”2. Parlamentarne oratorstwo renesansowe reprezentowane jest w dostępnych źródłach obficiej w swej warstwie programowej, merytorycznej (około 90\% zasobów) niż okolicznościowej, popisowej (około 10\%) ${ }^{3}$, przy czym w obu grupach mów znajdujemy wiele równie pięknych, klarownych i przekonujących konstrukcji. Oratorstwo barokowe natomiast uwiecznione zostało przede wszystkim w swej części popisowej. Źródła, tak rękopiśmienne, jak i drukowane, przekazuja w zdecydowanej większości (około 75\% zasobów) mowy okolicznościowe. Znacznie rzadziej natrafiamy na przejawy oratorstwa merytorycznego.

Zapisy oracji często bywają wtórne wobec prymarnej ich postaci mówionej, ale nawet jeśli teksty ułożone zostały na piśmie przed ich wygłoszeniem lub przeczytaniem (co też zdarzało się nierzadko), to powstawały z myślą o przekazie ustnym. Dostarczają więc cennego materiału badawczego do obserwacji niejednorodności

$1 \quad$ Cytat pochodzi z syntezy W. Bruchnalskiego Dzieje wymowy $w$ Polsce (w zb.: Dzieje literatury pięknej $w$ Polsce. Cz. 2. Kraków 1918, s. 323-333). Jego rozprawa broni się w tym zakresie przed etykietka przestarzałej, o czym dowodnie przekonuje J. Z. Li ch ańs ki („Dzieje wymowy w Polsce" Wilhelma Bruchnalskiego: refleksje po stu latach. W zb.: Proza staropolska. Red. K. Pła ch cińska, M. B a u e r. Łódź 2011). Tezę o „Zwrocie barokowym”, jako oczywistą, znajdziemy też w licznych późniejszych studiach J. Nowaka-Dłużewskiego, J. Rytel, J. Starnawskiego, E. Kotarskiego, J. Z. Lichańskiego, M. Korolki, M. Barłowskiej i innych.

2 Zob. K. Pła ch cińska, Obraz kultury retorycznej społeczeństwa szlacheckiego na podstawie mów sejmowych z lat 1556-1564. Łódź 2004.

3 Do sejmowych mów okolicznościowych, silnie skonwencjonalizowanych, nastawionych na popis i ceremonialność, należą powitania i pożegnania, podziękowania, obudowa oratorska przekazywania laski marszałkowskiej oraz zdawania i przyjmowania urzędów. Grupe programową reprezentują natomiast oracje służące inicjatywie ustawodawczej bądź niosące propozycje rozwiązania problemów. Mieszczą się tu: propozycje od tronu, wota senatorskie, projekty dokumentów, decyzje królewskie obwieszczane przez kanclerzy bądź przez samego monarchę, prośby i skargi posłów, wreszcie większość wypowiedzi stanowiących składniki dyskusji. Klasyfikację materiału oratorskiego z czasów Zygmunta Augusta, aktualną i w w. XVII, zob. ibidem, s. 23-28. 
i rozwarstwienia ówczesnej polszczyzny mówionej w sytuacji oficjalnej. Socjolekt szlachecki XVII w. ujawnia, jak wynika $z$ badañ ${ }^{4}$, oprócz cech wspólnych także wewnętrzne wieloaspektowe zróżnicowanie stylistyczne, uwarunkowane m.in. sytuacją aktu komunikacji i przeznaczeniem wypowiedzi. Jako definicję stylu przyjmujemy tu „zdeterminowaną funkcyjnie odmianę jakiegoś języka, o pewnych cechach stałych, dających się wydzielać ze zbiorów zjawisk językowych i uzależnionych od rzeczywistości pozajęzykowej"5. Dwa najbardziej pierwotne podziały języka literackiego, ogólnego: na typ pisany i mówiony oraz na sytuację oficjalną i nieoficjalną - krzyżują się, tworząc kilka klas wypowiedzi.

W ramach typu pisanego wyróżnia się styl artystyczny, publicystyczno-dziennikarski, naukowy i urzędowy. $Z$ punktu widzenia literaturoznawcy godzi się dodać tu jeszcze kategorię, która pomieściłaby prywatne listy, raptularze, diariusze, itineraria, a więc powstałe w sytuacjach nieoficjalnych.

Typ mówiony rozpada się na dwa podtypy - oficjalny (w jego ramach: styl retoryczny, publicystyczny, naukowy, urzędowy) oraz obiegowy (mieszczący styl informacyjno-bytowy i potoczny) $)^{6}$.

Wyróżnia się także styl wysoki, średni i niski. Wypowiedzi oficjalne realizować się mogą w odmianie wysokiej lub średniej, nieoficjalne zaś - w średniej. Odmiana niska, o bardzo silnym ładunku ekspresji, jest raczej wyjątkowa. Pamiętać przy tym należy, że w świadomości dawnych mówców, słuchaczy i teoretyków oratorstwo reprezentowało zawsze styl wysoki. Co prawda, stylistyka historyczna, jeśli uwzględnić kryterium funkcji, lokuje oracje polityczne w kręgu stylów prozy użytkowej, dokładniej - prozy polemicznej (obok tekstów urzędowych, dzieł naukowych i innych rodzajów prozy użytkowej, jak np. pamiętniki, listy, poradniki, szyldy, dedykacje, epitafia) $)^{7}$, ale sprzeczność jest tylko pozorna. Rozwój badań doprowadził do podniesienia rangi literatury użytkowej, a model retoryczny dobrze się sprawdza w badaniu każdego jej wymiaru, ponieważ zakłada rozumienie stylu jako środka do celu, nie zaś jako ozdoby, interesowanie się funkcją pragmatyczna tekstów i uwzględnianie w równym stopniu mówcy, słuchacza oraz przedmiotu ${ }^{8}$.

Jednocześnie obserwujemy, że w XVII stuleciu, zwłaszcza w jego drugiej połowie, zaczęły funkcjonować kryteria „artystyczności” także inne niż czysto retoryczne, oparte mianowicie na wyznacznikach epickich. Dostrzegamy wzrost autorytetu epiki w stosunku do renesansowej dominacji gatunków pozostających pod patro-

4 Zob. W. R. Rzepka, B. Walczak, Socjolekt szlachecki XVII wieku. (Próba ogólnej charakterystyki). W zb.: Barok w polskiej kulturze, literaturze ijęzyku. Red. M. S tę pi eń, S. U rbań c zy k. Warszawa-Kraków 1992. Tu bogata bibliografia, do której dodać należy prace M. Cybulskiego.

5 T. Skubalanka, S. Grabia s, Społeczne uwarunkowania stylów języka. „Socjolingwistyka” nr 2 (1979), s. 30.

$6 \quad$ Zob. D. Buttler, Miejsce języka potocznego wśród odmian wspótczesnej polszczyzny. W zb.: Język literacki i jego warianty. Red. S. U rb ań c zy k. Wrocław 1982, s. 27.

7 Zob. T. Skubalanka, Historyczna stylistyka języka polskiego. Przekroje. Wrocław 1984, s. 171-181.

8 Pogląd taki, dziś już klasyczny, przedstawili H. B elke (Problemy typologii i klasyfikacji tekstów użytkowych. Przeł. M. Łu k a s i e w i c z. „Pamiętnik Literacki” 1979, z. 3, s. 328-329) oraz T. S k ubala nka (Podstawy analizy stylistycznej. Rozważania o metodzie. Lublin 2001, rozdz. 14: Zastosowania pragmatyki $w$ analizie stylistycznej). 
natem retoryki, $z$ równoczesna płynnością gatunkową utworów, wymykającą się klasyfikacjom, $z$ ciagłym przekraczaniem granic między prozą artystyczną a nieartystyczną, z wzajemnymi wpływami i splataniem się wzorców ${ }^{9}$. Spostrzeżenia te dotyczą przede wszystkim sfery prozy narracyjnej, ale przecież nie rozwijała się ona w próżni, a jej przemiany stanowiły m.in. efekt trwającej równolegle ewolucji prozy retorycznej. Była to zależność obustronna.

Taką bowiem właśnie niejednorodność, płynność i przekraczanie granic obserwujemy też w mowach sejmowych, gdy poszczególne cechy stylowe oratorstwa politycznego: perswazyjność, sugestywność, emocjonalność, impresyjność i okresowość składni ${ }^{10}$ - realizowane są w zmiennym nasileniu. Ilekroć przy analizie mów parlamentarnych natrafiamy na poluzowanie wzorca retorycznego, co w wypadku wypowiedzi programowych zdarza się nierzadko, tylekroć zdani jesteśmy na własną intuicję badawczą i trudno zdecydować, czy obok fragmentów w stylu retorycznym (niewątpliwie model wysoki) widzimy partie wypowiedzi w stylu publicystycznym, słabiej nasyconym retoryką, reprezentującym model średni, czy też, mając do czynienia wciąż ze stylem średnim, wchodzimy już jednak w podtyp obiegowy, w polszczyznę potoczną. Nadal przecież pozostajemy w sytuacji najzupełniej oficjalnej. Spostrzeżenia będące wynikiem takich wątpliwości przyczynią się, być może, także do wzbogacenia obszaru stylistyki. Zjawisko potoczności w języku polskim XVII w. nie jest dotąd gruntownie zbadane ${ }^{11}$.

Przede wszystkim dostrzegamy wyrazistą odmienność wymowy popisowej od merytorycznej. Ta pierwsza grzeszy schematyzmem, powtarzalnością toposów oraz przesadną ozdobnością i „wysokością” stylu, druga zaś na odwrót - często zdaje się ledwo przejmować funkcją delectare, dążąc ku niewyszukanej zwyczajności wypowiedzi. Nie dba przy tym o jednorodność stylistyczną, mieszając - nawet w ramach tej samej wypowiedzi - styl wysoki ze średnim. Oczywiście, natrafiamy na wyjątki po obu stronach, tak wszakże wygląda obraz statystyczny. Być może, przyczyna przewagi zapisów oracji okolicznościowych stało się właśnie to, że reprezentowały one bezpieczny, bo znany, wpojony głęboko w procesie edukacji szlachcica, model piękna. Rozwój wymowy popisowej znalazł się jednak na równi pochyłej, o czym przekonuje zdegenerowane głęboko oratorstwo czasów saskich. Wystapienia merytoryczne natomiast, choć wzgardzone przez kopistów, warto, jak się wstępnie wydaje, dokładniej zanalizować, skoro obserwujemy w nich znamienne zróżnico-

Zob. J. Rytel, Z problematyki gatunków literackch $w$ prozie staropolskiej. W: Studia z dziejów prozy staropolskiej. Warszawa 1993, s. 30-32.

10 Pojęcie cechy stylowej wprowadza B. Wy derka (Perswazyjność jako cecha stylowa gatunków prozy publicystycznej XVII wieku. W zb.: Odmiany polszczyzny XVII wieku. Red. H. W iśn i e w s ka, Cz. Ko s y l. Lublin 1992, s. 85-87).

11 Ani co do definicji stylu, ani co do rozumienia potoczności nie ma wśród językoznawców pełnej zgody. Przyjmuje się tu w wypadku każdego $\mathrm{z}$ tych pojęć jedno $\mathrm{z}$ wielu stanowisk, najlepiej odpowiadające założeniom literaturoznawstwa staropolskiego. W zakresie badań nad stylami polszczyzny XVII w. wartościowe są prace W. Kuraszkiewicza, K. Siekierskiej, H. Wiśniewskiej, M. Wojtak, B. Walczaka; brak na razie syntetycznego obrazu jezzyka mówionego w XVII stuleciu. Gruntowna ksiażka E. Umińs ki ej-Ty toń Polszczyzna potoczna XVIII wieku (Łódź 1992) dotyczy czasu, gdy zmiany dokonujące się w XVII w. już się zakończyły. Znajdujemy tu więc cenne wskazanie tendencji rozwojowych znamiennych dla poprzedniego stulecia. 
wanie stylistyczne. Interesujące jest, jak daleko ono postępuje i jakimi narzędziami retorycznymi zostaje wprowadzone. Dojście do syntezy wymaga wcześniejszych badań szczegółowych.

Wypowiedzi kasztelana poznańskiego Krzysztofa Grzymułtowskiego ${ }^{12}$ godne tu są analizy $z$ dwóch powodów. Po pierwsze dlatego, iż był on postacią dla swoich czasów bardzo charakterystyczną: koniunkturalista, reagujący na zmienność układów, by bezwstydnie wykorzystać te, które sprzyjały jego ambicjom i majątkowi, spiskujacy z obcymi dyplomatami, demagog, przy tym magnat niezwykle wpływowy, lokujący się w centrum wydarzeń. Po drugie z tej przyczyny, że uchodził za oratora utalentowanego, a liczne jego mowy trafiły do rękopiśmiennych przekazów oratorskich. Na podstawie utrwalonego w nich kształtu perswazji stosowanej przez kasztelana wnosić więc można o kulturze retorycznej, jaką odznaczała się szlachta w czasach Jana Kazimierza. Próbką poddaną obserwacji jest wotum Grzymułtowskiego wygłoszone na sejmie 16 marca 1665, dostępne w przekazie rękopiśmiennym z drugiej połowy w. XVIII, przechowywanym w Bibliotece Kórnickiej ${ }^{13}$.

Sejm ten, zwołany jako nadzwyczajny, dwutygodniowy, zająć miał się wyłącznie, co postanawiały legacje na sejmiki, sprawą nieopłaconego wojska, grożącego konfederacją. Ponieważ jednak była to gorąca chwila tuż przed wybuchem rokoszu Jerzego Lubomirskiego ${ }^{14}$, przebieg obrad wyglądał inaczej ${ }^{15}$. Inauguracja sejmu

12 Urodzony w r. 1620, potomek zamożnej rodziny wielkopolskiej, Krzysztof Grzymułtowski był po kądzieli wnukiem Wacława Leszczyńskiego - kanclerza wielkiego koronnego, a powtórny ożenek owdowiałej matki, Katarzyny, $\mathrm{z}$ wojewodą podlaskim Piotrem Opalińskim spowinowacił go z kolejnym potężnym rodem wielkopolskim. Był nieźle wykształcony (Poznań i kolegium jezuickie w Dôle we Francji); próbował też sił w młodzieńczej twórczości literackiej. Od roku 1648 nieprzerwanie posłował na sejmy, ciesząc się wśród szlachty popularnością i uczestnicząc w wielu komisjach, a latem 1654 pełnił nawet funkcję marszałka poselskiego. Zob. Grzymułtowski Krzysztof. Hasło w: Polski stownik biograficzny. T. 9. Wrocław 1960.

13 Bibl. Kórnicka, rkps 356, k. 161-163. Manuskrypt ten zawiera akta polityczne dotyczące dziejów Polski w latach 1605-1690, w zdecydowanej większości oracje sejmowe, ale także sejmikowe i z obozów wojskowych, oraz listy. Ciekawostką jest wierszowana relacja z przebiegu rady senatorów przy królu w 1662 roku. Zapisy na ogół (z wyjątkami) zachowują chronologię. Zauważamy kilka różnych rąk pisarskich. Proweniencja nieczytelna, $z$ datą 1755 lub 1785, lub 1788. Zawiera notkę: „Nabyty z Bud Złotkowskich pod Kleczewem. 1842. Trąmpczyński”.

Mowa Grzymułtowskiego nosi tytuł: Votum Jego Mci Pana Krysztofa Grzymultowskiego Kasztallana Poznańskiego na sejm dwuniedzielny 1665. W przytoczonych tu cytatach transkrypcja według reguł dla wydań typu B, skodyfikowanych w wytycznych zawartych w: K. G ó rs ki [i in.], Zasady wydawania tekstów staropolskich. Projekt. Przykłady oprac. J. W o r o n c zak. Red. M. R. May e n ow a, przy współpr. Z. Flor c zak. Wrocław 1955.

14 W maju 1665 wkroczenie eksmarszałka Lubomirskiego $\mathrm{z}$ wojskiem na teren Rzeczypospolitej, w lipcu i sierpniu 1666 zawarcie ugody w Łęgonicach i uroczystość przeprosin króla pod Jaroszynem. Rokosz pozornie zakończy się sukcesem dworu, w istocie jednak - klęską projektów reform i głęboko sięgająca erozją zaufania społecznego.

15 Ostra walka sejmikowa wyłoniła posłów, w większości zwolenników restytucji Lubomirskiego, można więc było oczekiwać, że problem nieopłacenia armii, niezgodnego ani z dobrem kraju, ani z treścią uniwersału sejmowego, uniemożliwi sprawny przebieg obrad i uchwalenie konstytucji. Tak się też stało. W interesie eksmarszałka było, grożące wznieceniem niepokoju, pozostawienie wojska bez zapłaty. Posłowie opozycyjni zastosowali metodę konsekwentnej obstrukcji obrad (rugami poselskimi, dyskusją o legalności sejmu, słuchaniem relacji marszałka Jana Gnińskiego Z poprzedniego sejmu), zakończonych protestem Władysława Łosia i zerwaniem sejmu. Zob. 
mszą wotywną do Ducha Świętego odbyła się 12 marca, w czwartek. W homilii kaznodzieja królewski Adrian Piekarski ostrzegał przed rozbiciem nawy Rzeczypospolitej o skały: o występki i przyzwolenie na nie, o prywatę, o brak zaufania do króla. Brał monarchę w obronę, dowodząc, że wypełnianie praw jest królom przyrodzone, a jeśli monarcha modyfikuje prawo, to w celu ulepszenia go - dla dobra państwa. Wyraziste były w kazaniu aluzje do działań Lubomirskiego, grożących „pożarem” ${ }^{16}$. Wybrano też marszałka Izby Poselskiej, podkomorzego smoleńskiego Jana Antoniego Chrapowickiego. Następnego dnia odbyła się ceremonia powitania króla, a w sobotę, 14 marca, kanclerz wielki litewski Krzysztof Zygmunt Pac wygłosił propozycje od tronu. Dotykała ona niemal wyłącznie spraw obrony: zapłaty wojskom borgowym, podjęcia decyzji co do stosunków z Moskwą i wyznaczenia komisarzy do rokowań, opatrzenia fortec pogranicznych, a także reformy funkcjonowania mennic ${ }^{17}$.

Przewodnictwo obrad, $\mathrm{z}$ powodu choroby marszałka Aleksandra Teodora Lackiego, objął najwyższy krzesłem $z$ obecnych senatorów świeckich, kasztelan poznański. Obstrukcyjne działania posłów zdążyły się już zaznaczyć, gdy rozpoczęły się wota senatorskie. Tegoż dnia wotowało dwóch biskupów: płocki, Jan Gembicki, i chełmski, Tomasz Leżeński. W poniedziałek, 16 marca, wotowało 11 senatorów, w tym gronie Grzymułtowski. Obserwujemy tu wystapienie kasztelana poznańskiego w chwili, gdy nie przyłączył się on jeszcze jawnie do rokoszu, ale decyzję tę już podją ${ }^{18}$. Tylko jego wypowiedź wywarła wrażenie na słuchaczach. Poza nią, jak notują świadkowie, normą było nieomal powtarzanie wypowiedzi poprzedników i „referowanie się na puncta propozycyjej” ${ }^{19}$. Charakterystyczne są oceny zawarte w diariuszach: „nic nie mówił pro commodo Reipublicae [w interesie Rzeczypospolitej]” (o biskupie Gembickim), „nie piękniejszymi słowy niż głosem, bo piskliwym i charkliwym jakimsi dyskursem [!] mówił i niewiele do rzeczy" (o wojewodzie sieradzkim Wierzbowskim), „barzo coś cicho, choć długo” i „ten głowy nie przełomał, tylko interesa swoje promował" (o podskarbim Krasińskim) ${ }^{20}$.

Wotum Krzysztofa Grzymułtowskiego, zapisane w sposób ciągły, składa się z 34 odcinków, kończących się w rękopisie kropką. Nazywane tu one będą periodami, z zastrzeżeniem, że znaleźć można wśród nich zarówno prawdziwe okresy retoryczne $\mathrm{z}$ dwudzielną strukturą: protasis i apodosis, jak też oratio perpetua oraz oratio

W. Kł a c z e w s ki, W przededniu wojny domowej $w$ Polsce. Walka sejmowa lat 1664-1665. Lublin 1985, s. 98. - S. O ch mann-Staniszew ska, Z. St an is zew ski, Sejm Rzeczypospolitej za panowania Jana Kazimierza Wazy. Prawo - doktryna - praktyka. T. 1. Wrocław 2000, s. 376-405. Kłaczewski, op. cit., s. 111-112.

Zob. Ochmann-Staniszewska, Staniszewski, op. cit., s. 376-382.

18 W nadziei awansów wyższych niż kasztelania poznańska (1656) pozostawał Grzymułtowski regalistą do 1662 roku. Do rokoszu przystapi otwarcie dopiero w lipcu 1665, gdy wojna domowa stanie się faktem. Dowodzić będzie pospolitym ruszeniem Wielkopolan pod Pyzdrami, dając Lubomirskie$\mathrm{mu}$, operującemu dotąd oddziałami zaciężnymi, legitymację obywatelską. W dalszym przebiegu rokoszu pełnić będzie funkcję de facto zastępcy eksmarszałka. Zob. A. J a bł o n ow s ki, Krzysztof Grzymultowski wojewoda poznański. W: Krzysztofa Grzymultowskiego wojewody poznańskiego listy i mowy. Wyd. ... Warszawa 1876, s. XV, XVIII-XIX.

19 Diariusz Sejmu Zerwanego A 1665 [...]. AGAD, APP 321, s. 9-12. Cyt. za: O c h mann-Staniszewska, Staniszewski, op. cit., s. 384. 
soluta. Natomiast cząsteczki wewnętrzne, składające się na tak rozumiane periody, nazwiemy umownie kolonami. Stanowia je człony intonacyjno-składniowe wyodrębnione domyślnie tak, jak wyobrażamy sobie rozczłonkowanie intonacyjne strumienia mowy ${ }^{21}$.

Manuskrypt z Biblioteki Kórnickiej najwyraźniej nie zawiera całości wypowiedzi, gdyż pozbawiony jest formuły zakończenia, a cząstka ostatnia: „Ekonomija [...] bełska, artyleryja i insze punkta”, stanowi streszczenie dalszych fragmentów oracji, nie zapisanych $\mathrm{w}$ dostępnym przekazie.

\section{Postulaty}

Wotum ma budowę segmentową. Po zakończeniu exordium dotyka w swej warstwie merytorycznej pięciu problemów, postulując:

I. Zadecydowanie w obecności wszystkich (zamiast delegowania tego obowiązku na deputatów) o kierunku i zasadach rokowań z Moskwą.

II. Odsunięcie wszelkimi sposobami (walką, działaniami sejmowymi, łaskawym pobłażaniem) zagrożenia wojną domową.

III. Potrzebe pospolitego ruszenia.

IV. Rozdzielenie finansowania wojska między województwa.

V. Ujawnienie zakresu korupcji związanej z biciem monet i podwyższenie wartości dobrego pieniądza.

Postulaty wyłożył mówca, kolejno w każdym segmencie, bardzo jasno i konkretnie:

I. Życzę na tym sejmie formare ad tractandum [sporządzić do rokowań] z carem moskiewskim instrukcyja praesente Reipublicae [w obecności Rzeczypospolitej, tzn. złączonych stanów] $[\ldots]$.

II. [...] suplikuje pokornie,

abyśs [królu] część - waleczną,

część - praesenti consilio [obecną radą],

część - łaskawą klemencyją,

miłościwie od ojczyzny avertere [odwrócić] raczył [...].

III. Życzę tedy,

W[asza] K[rólewska] M[iłość], ad hanc casum [w tym wypadku] pospolite ruszenia [...].

IV. Tak tedy rozumiem najlepszy modus [sposób] płacenia:

wojska na województwa podzielić,

odebrawszy wprzód co do przyszłej płacy informacyja,

wiele też wojska w której ćwierci,

by to potym przysięgą miałoby być stwierdzoną,

a ten jurament województwo każde przy płacy uważyć.

V. Życzyłbym,

N[ajjaśniejszy] M[iłoś]ciwy Królu,

aby tenże popisał się $z$ konceptem,

jako by to,

co zepsował,

naprawić,

a nie sentencyjką na monetę nową, 
ale radą zdrową,

jako by srebro i złoto,

które $z$ Polski wyprowadzieł,

znowu wprowadzić.

Ja sposobu nie widze,

chyba podwyższenie dobrych pieniędzy [...].

Proszę tedy pokornie WKMci i R[zecz]P[ospoli]tej,

aby pod przysięgą zeznał [Tymph] ${ }^{22}$,

wiele dał komu [korupcyjej]

i wiele wybił na privatos usos [na prywatny użytek] [...].

\section{Konstrukcja segmentów}

Poszczególne segmenty zbudowane są w sposób powtarzalny, $\mathrm{z}$ typowych elementów: opowiedzenia, sformułowania postulatu, argumentacji (ewentualnie zakończonej wnioskiem) i przedstawienia korzystnych skutków proponowanych działań. Skutki te określił mówca jako ,fructa”. Oto dla przykładu segment I (periody 4 i 5):

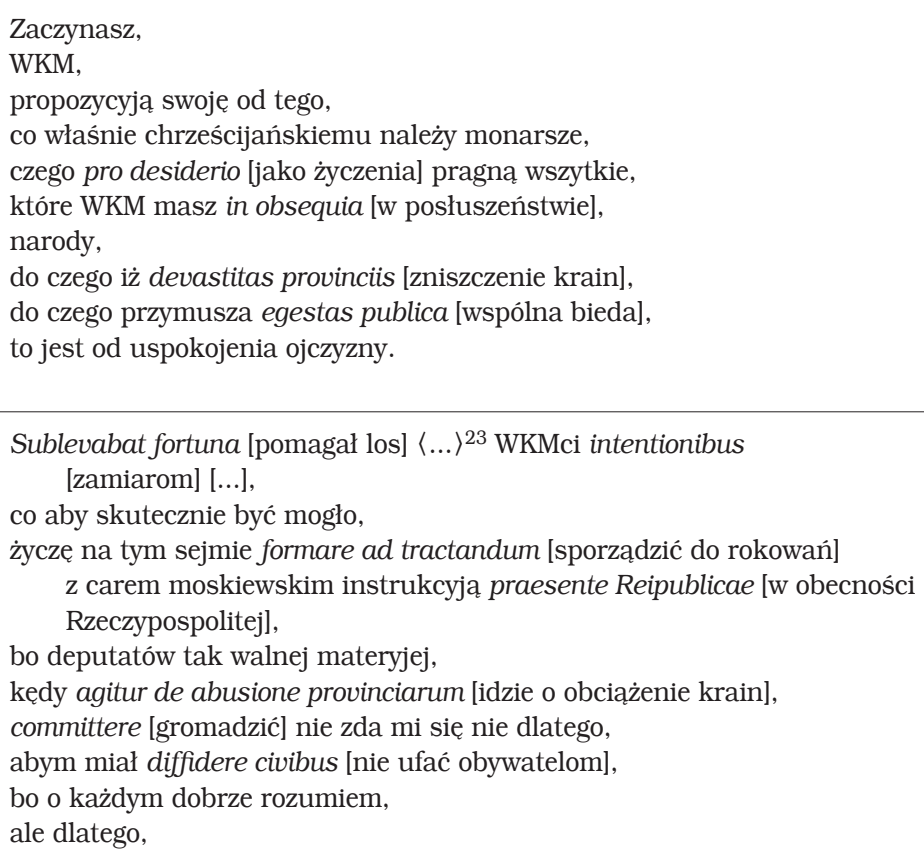

Sublevabat fortuna [pomagał los] $\langle\ldots\rangle^{23}$ WKMci intentionibus

[zamiarom] [...],

co aby skutecznie być mogło,

życzę na tym sejmie formare ad tractandum [sporządzić do rokowań] $\mathrm{z}$ carem moskiewskim instrukcyja praesente Reipublicae [w obecności

Rzeczypospolitej],

bo deputatów tak walnej materyjej,

kędy agitur de abusione provinciarum [idzie o obciążenie krain],

committere [gromadzić] nie zda mi się nie dlatego,

abym miał diffidere civibus [nie ufać obywatelom],

bo o każdym dobrze rozumiem,

ale dlatego,

Bracia Tymfowie (Andrzej i Tomasz) byli, obok Tytusa Boratiniego, dzierżawcami mennic. W wotum mówi Grzymułtowski o Andrzeju, pełniącym funkcję zarządcy mennic koronnych, słusznie oskarżanym przez szlachtę o ogromne nadużycia na szkodę skarbu państwa. Zalew złej monety stanowił jedną z ważnych przyczyn inflacji i destabilizacji gospodarczej. Zob. R. Ry b a r s ki, Skarb i pieniadz za Jana Kazimierza, Michała Korybuta i Jana III. Warszawa 1939, s. 393-400.

23 W rękopisie wyraz nieczytelny, trudny tu do odgadnięcia; dalej, w przypadku wyrazów nieczytelnych, $\mathrm{w}$ nawiasach ostrych podawany jest sens wynikający z treści. 
żeby tym samym,

którzy by się tego podjęli,

periculosum inde conv〈enit〉 [groziło stamtąd niebezpieczeństwo],

gdyby praca na obrót potym przychodzić miała,

więc mamy próbę,

że takowe deputacyje nigdy albo rzadko fructum Reipublicae [efektu

Rzeczypospolitej] nie przynosiły,

a to i teraz snadź recenter [ostatnio] żadnej nie było mistracyjej,

więc contagium [złym przykładem] zda mi się kilka in statu nostro de

summa rerum [w naszej sytuacji o najważniejszych sprawach]

decydować,

tedy równo tu na tym placu to wszystko znosić,

co należy do uzgodnienia,

żeby kiedyżkolwiek skutecznie W[ielkie] Ks[ięstwo] Litewskie od tak ciężkiego uwolnić ciężaru,

za którym oraz nieomylnie w Ukrainie pokój subsequi [nastąpić] musiałby,

argument 4: refutatio

i tak swawolne rebelles [bunty] musiałyby przyjąć [go, tj. pokój] z ręki WKMci P[ana] N[aszego] M[iłoś]ciwego.

\section{Tranzyty}

Zręczne przechodzenie ku kolejnym zagadnieniom zapewniają transitiones, skonstruowane zróżnicowanymi technikami. Przejście ze wstępu do segmentu I jest nawiązaniem do myśli zawartej w exordium: król zwołuje co rok sejm, by można było „wszytkich calamitatum in saltis avertere [nieszczęścia w knieje wygnać]”.

A oto transitio:

A że te,

któreś WKM upadki następujące na Rptą 〈przewidział〉,

do uwagi podać nam miłościwie raczyłeś,

[...]

pod uwagę WKMci po wtóre liche moje przypominam sentire [zdanie].

Podobna konstrukcja łączy segment II $z$ I, w którym mowa o wytęsknionym pokoju na Litwie i na Ukrainie po traktatach z Moskwą. Transitio zaś brzmi:

A że WKM PNMciwy pokoju życzysz ojczyźnie,

$[\ldots]$.

Również transitio segmentu III (tego o pospolitym ruszeniu, ważnego dla interesów mówcy) wprowadzone zostało w odniesieniu do ostatniego zdania części poprzedniej, wyrażającego pragnienie pokoju:

Ale że nie jest to cale w ręku WKMci ten ab intra iubere [wewnętrzny zarządzić] pokój, [...].

Transitio do kolejnego segmentu opiera się na toposie zwięzłości:

De modo [o sposobie] tylko płacenia rzekę krótko,

[...]. 
Przejście do części V operuje figurą obsecratio i wskazaniem ogromu zagadnienia, kompozycyjnie jednak pozbawione jest nawiązania do segmentu poprzedniego:

Minnicę kto by chciał ganić,

o Boże mój,

jako by miał szyrokie pole dać [...].

\section{Opowiedzenia}

Rolą opowiedzenia (narratio) w mowie retorycznej jest przedstawienie stanu rzeczy, co następnie powinno pozwolić na sformułowanie problemu. Dobra narratio ma zawierać zasiew dowodzenia.

Sprawę pierwszą, pertraktacje z Moskwą, wyprowadził Grzymułtowski, jak widać $\mathrm{w}$ cytacie $\mathrm{z}$ periodu 4, wprost $\mathrm{z}$ Propozycyi królewskiej. Powszechne pragnienie pokoju, wyniszczenie i zubożenie kraju - to fakty stanowiące przedmiot narratio. Są one także argumentami na rzecz uregulowania stosunków polsko-moskiewskich, $\mathrm{z}$ tym jednak że przecież w tej sprawie nikt nie miał odmiennego zdania.

W latach 1660-1665 trwało stopniowe odzyskiwanie równowagi między Polską a Rosją po bardzo niekorzystnych wydarzeniach lat 1654-1655, zakończonych traktatem w Niemieży, pozostawiającym większość terenu Litwy pod władzą Moskwy. Kampania 1660-1661 była wielkim sukcesem Polski, lecz przerwana została z powodów finansowych: zawiązaniem konfederacji wojskowych przez nieopłacone oddziały. Z kolei wyprawa 1663-1664, zaplanowana jako ofensywa w głab Rosji, z zamiarem dotarcia do jej stolicy (dla ostatecznego rozstrzygnięcia konfliktu i wzmocnienia autorytetu Jana Kazimierza w społeczeństwie), osiagnęła rezultaty niewspółmiernie nikłe w stosunku do ogromnego wysiłku zmagań na Zadnieprzu. Rosjanie konsekwentnie unikali walnej bitwy. Wreszcie, po licznych oblężeniach i potyczkach, zarządzono odwrót. Mimo to kampania 1663-1664 była wyraźnym pokazem siły Rzeczypospolitej, zwłaszcza że kilkutysięczny zagon polsko-litewsko-kozacki dotarł w końcu lutego 1664 w pobliże Moskwy, rozbijając wojska wroga. Wyprawa ta zaważyła na kształcie zawartego ostatecznie 30 stycznia 1667 w Andruszowie pokoju, który regulował stosunki obu państw w obliczu narastającego niebezpieczeństwa tureckiego ${ }^{24}$.

Wiosną 1665 konieczność i znaczenie rokowań z Moskwą były więc oczywiste.

Także w segmencie II (zapobieżenie wojnie domowej) narratio ukształtowana została $\mathrm{w}$ odniesieniu do życzeń władcy, choć tym razem nie wyprowadzonych z Propozycyi, lecz wyrażonych poprzez przypisywanie mu wiedzy i dobrej woli (w periodzie 6):

[...] WKM pokoju życzysz ojczyźnie,

a podobno nie tylko ab extra [z zewnątrz],

ale też $a b$ intra [wewnątrz],

jakież nam fata [losy] gotują turbas [niepokoje], 
które $\mathrm{z}$ tej strażnice [widzisz],

na której Bóg wszechmogący pastorem et custodem [pasterzem i strażnikiem],

wiem,

posadził WKM.

Nietrudno zauważyć zastosowaną tu figurę dialektyczną concessio: przytoczenie zdania przeciwnika $z$ pozorna aprobatą. Tym sposobem już $w$ opowiedzeniu przemycona została argumentacja na rzecz podjęcia sprawy Lubomirskiego, nie przewidzianej wszak do procedowania: skoro, królu, pragniesz pokoju, a przecież sam głosisz, że także wewnętrznego..., to „suplikuje pokornie [...]”.

W segmencie poświęconym pospolitemu ruszeniu opowiedzenie (period 8) opiera się na stwierdzeniu na tyle oczywistym dla wszystkich, że poszło nawet w przysłowie: „Si vis pacem, para bellum [Jeśli pragniesz pokoju, szykuj się do wojny]”.

expedit [warto] być i na wojnę gotowym,

boć sub dubio [przy niepewności] traktując,

gruntowniejszego,

ozdobniejszego spodziewając się pokoju,

trzeba tedy mieć śliczne [!] wojska [...].

Segment kolejny operuje opowiedzeniem referującym poruszany problem jako postulowany już wcześniej na forum sejmowym, a więc nienowy, oczywisty (w periodzie 16):

recenter [ostatnio] za drugim,

fallor [mylę się],

albo trzecim sejmem

postrzegła się Rpta,

expedire [że warto] uczynić do płacy podział wojska na województwa [...].

Problem piaty (mennica, w periodzie 27), po tranzycie wydobywającym ogrom sprawy, opowiedziany zostaje w konwencji osądu, nie pozostawiającego wątpliwości co do zaistnienia zła i przyszłej kary wobec winnych - podwójnej: Boskiej, idącej w pokolenia, i niesławy. Dodać tu należy, że wszystkim ówczesnym wypowiedziom na temat pieniądza towarzyszył równie emocjonalny ton i podobne obrazowanie:

ktokolwiek tak złą [mennicę] wymyślił,

złożył był z serca bojaźń Bożą i wszelka poczciwość,

ten bowiem wiele Polski zepsował 〈wyprowadzając złoto〉 nasze zgromadzone,

ten przerobił złota polskie w miedziane,

ten ostatnią krew $\mathrm{z}$ nas wyssał,

za co niepodobna,

aby sprawiedliwość Boska z niego i potomstwa jego wziąc nie miała vindictam [pomsty],

niepodobna,

aby posteritas [potomność] jego imienia między największych łotrów położyć nie miała.

Oto więc wspólna cecha narrationes zastosowanych w wotum Grzymułtowskiego: przedstawianie oczywistości, zwięzłe nazywanie problemu jako niezaprzeczalnego faktu, a przy tym skłonność do korzystania z tego „twardego” podłoża dla ułatwienia przejścia do argumentacji. 


\section{Dowodzenia}

Probacja i refutacja stanowia jądro inwencyjne każdej wypowiedzi retorycznej i polegają na wynalezieniu, a potem odpowiednim zaprezentowaniu różnego rodzaju dowodów (argumentationes).

W segmencie I wotum kasztelana poznańskiego znajdujemy, jak widać w przytoczonym periodzie 5, wyraziste toposy zewnętrzne. Dwa $z$ nich, o charakterze probacyjnym, wywodzą się z powszechnego przekonania, że warunki pertraktowania z Moskwą to sprawa: 1) „walna”, a zatem ogólna, powszechna; 2) powodująca swymi rezultatami obciążenie niektórych prowincji. Sa to oczywiście stwierdzenia prawdziwe, ale jako argumenty - niewystarczajace. Nie wynika z nich bezpośrednio postulat wypracowywania instrukcji do rokowań na forum sejmu (co przecież zatrudniłoby parlament na długo) zamiast w łonie powołanej do tego zadania komisji. Dlatego pojawiaja się trzy kolejne dowody, tym razem refutacyjne. Dwa $z$ nich dotyczą ewentualnych członków takiej komisji. Najpierw zastrzega się mówca, stosując figurę dialektyczną reiectio, że jego postulat nie pochodzi z braku zaufania do współobywateli, że on „o każdym dobrze rozumie”. Było to jawnym fałszem, gdyż chęć roztrząsania warunków rozmów z Rosją „praesente Reipublicae” wynikała właśnie wprost $z$ podejrzeń wobec deputowanych o brak obiektywizmu. Figura ta odegrała rolę słodkiej polewy na gorzkiej aplikowanej pigułce. Następnie, jakoby troszcząc się o członków komisji, senator obawia się „periculosum [niebezpieczeństwa]", które groziłoby im potencjalnie w wypadku złego obrotu wydarzeń. To akurat mogłoby okazać się prawdą, a jako argument nie wzięło się zapewne znikąd. I wreszcie topos z doświadczenia: takie komisje nie sprawdzały się. Po tym skumulowaniu dowodów (congeries jako narzędzie amplifikacji) znów pojawia się postulat, teraz już w randze wniosku: „tedy równo tu na tym placu to wszytko znosić, co należy do uzgodnienia”. Jako argumenty ostateczne przywołuje Grzymułtowski powierzając im przy tym rolę peroratio - fructa z przyjęcia postulowanego rozwiązania: zdjęcie ciężaru z Litwy, a następnie pokój na Ukrainie.

Zadziwiająco ascetycznie, ale jedynie na pozór, przedstawia się natomiast dowodzenie na rzecz kolejnego postulatu: supliki do króla o uchronienie kraju każdym możliwym sposobem przed wojną domową (period 7):

\section{Lecz wierzę,}

bo nie tylko masz osobliwa,

którą monarchowie miewają $\mathrm{z}$ aniołów Boskich, asystencyja,

ale też ową,

którą meruisti [wysłużyłeś] u Boga virtutibus tuis [twymi cnotami], o którą kiedyś mądry monarcha suplikował Boga tronem królewskim, sapientiam [mądrość].

Mówca niby to zrzeka się prawa do argumentacji, stając w obliczu nadprzyrodzonych walorów monarchy, takich jak jego pozostawanie pod opieką aniołów i szczególna mądrość, wysłużona u Boga cnotami, porównywana z Salomonową. Oprawę elokucyjną tworzy tu semantyczna figura zwrotu, zwana permissio. Władcy tak hojnie wyposażonego przez niebo nie wypadałoby przekonywać. Do wyrażo- 
nej w ten sposób dobrej opinii o Janie Kazimierzu (nie wnikamy na razie w jej szczerość) wypadnie jeszcze wrócić. Uchylenie się od jawnej argumentacji nietrudno zrozumieć. Grzymułtowski wyciaga przecież problem obcy intencjom króla, dla którego sprawa była najwidoczniej zamknięta. Mówić jaśniej byłoby niezręcznie, stąd elegancka, a przy tym sprytna figura retoryczna. Jednak po wyrażeniu postulatów, by podjąć sprawę Lubomirskiego na sejmie i poddać ją „łaskawej klemencyi”, pojawiają się jeszcze, jak zwykle, argumentacyjno-peroracyjne fructa:

żebyż [my] wżdy kiedy mogli za dni naszych żyć spokojnie,

ratować zniszczonych substancyjej naruszonych,

które nad złoty [!] ważymy w swobodach.

Początek brzmi jak dążenie czysto ekonomiczne, wyrażające powszechną tęsknotę do pokojowego bytowania i odbudowy zrujnowanych majątków. Kolon ostatni jednak kieruje rzecz na inne tory. „Naruszone substancyje” okazuja się nie tyle posiadłościami i majątkami, ile raczej swobodami, które doznały zniszczenia i domagają się ratunku.

Po to więc potrzebny był cały ten wcześniejszy „miód” pod adresem władcy, by pozwolić sobie na ostrą zaczepkę w finale. Oto wymowa całości (wraz z narratio): Jesteś, królu, tak mądry, iż nie trzeba ci szeroko dowodzić, że ważna i nie zakończona jest sprawa Lubomirskiego; pamiętaj też, że Bóg uczynił cię naszym pasterzem i obrońca, a to nakłada odpowiedzialność.

Wyjątkowo rozchwiany kompozycyjnie okazuje się segment III (periody 9-15), domagający się zwołania pospolitego ruszenia. Problem nieopłaconego wojska, stanowiący w istocie treść części następnej, pojawił się tu jako argument na rzecz postulatu Grzymułtowskiego (dodajmy: wielokrotnie wysuwanego wcześniej przez Lubomirskiego). Jego realizacja oznaczałaby podporządkowanie wojska magnatom, co w zamierzeniach eksmarszałka ograniczyć miało władzę króla i pogłębić anarchię $^{25}$. Efekt powołania pospolitego ruszenia wielkopolskiego można było zreszta zaobserwować w praktyce 7 miesięcy później, gdy Grzymułtowski przyprowadził Lubomirskiemu 3 tysiące szabel, zmieniając tym samym względnie korzystny dotąd dla dworu układ sił ${ }^{26}$.

Zastosował tu mówca kilka różnorakich pomysłów argumentacyjnych. Na początek refutacja, całkiem racjonalna i nieodległa od prawdy - nie da się odpowiednio szybko zebrać pieniędzy dla wojska (period 9):

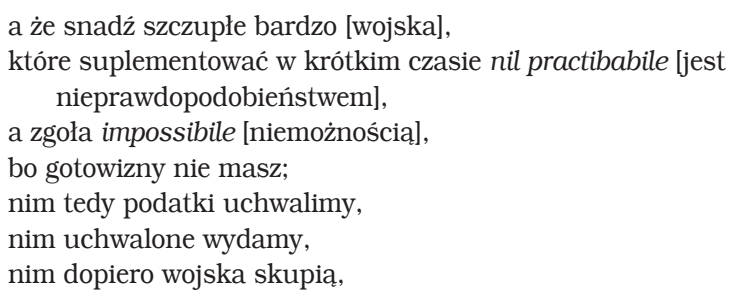

zbyt długa procedura zbierania pieniędzy 
pora wojenna nie tylko,

ale podobno i nastapi;

bo mamy próbę,

z jakim ciężarem przez półtrzecia lata wybierano na przeszłe płace sumy

$[\ldots]$

bez których [tj. podatków] nie popłacimy wojska,

lubobyśmy do kolektora rzucili się,

luboby i superfluentes [obfite potoki] poszły w gromade,

tedy milionów,

które wojska obudwu narodów debentur [wymagają jako wierzytelności],

$\mathrm{z}$ tego nie będzie.

W tym momencie pojawia się postulat powołania pospolitego ruszenia, jakby wynikał on z przedstawionego argumentu: „Życzę tedy [...]”. Tu kończy się logika dowodowa, a zaczyna się demagogia. $\mathrm{W}$ dalszej argumentacji powiązane zostają nierozerwalnie dwie sprawy różne, ale traktowane przez mówce jako jedna: potrzeba opłacenia wojska i powołanie pospolitego ruszenia. Tak powstaje „mętna woda”, ułatwiająca „połów ryb”. Oto topos Boskiej przychylności albo kary, budujący probację:

co wiedzieć,

jeżeli przy nim [pospolitym ruszeniu] Bóg nie pobłogosławi prędzej WKMci intencyjej uspokojenia ojczyzny

i nie prędzej stanie wojsko,

$[\ldots]$.

Jakoż jeszcze życzę $[\ldots]$,

aby kiedykolwiek ustała ta ciężkość na ludzi niewinnych,

których nie tak nieprzyjaciel,

jako nomine [imiennie] niektórzy

(bo nie wszyscy)

〈ciemiężą〉,

aby zrujnowawszy regiment,

mieli okazyja de novo [na nowo] mordować i ostatnią krew ssać ludzi ubogich,

za co oboje tak drapieżnym i krwie niewinnej pełnym rękom nie chce Bóg dać zwycięstwa,

i owszem,

nas $\mathrm{z}$ nimi,

i znowu nas i onych nieprzyjacielem karze.

Prawdziwy argument o niewątpliwym ciężarze perswazyjnym, czyli podkreślenie dolegliwości faktu, że nieopłacone wojsko szuka chleba na własną rękę, połączony zostaje demagogicznie $\mathrm{z}$ przewidywaniem Boskiej nagrody dla pospolitego ruszenia i kary dla wojsk zaciężnych.

Następnie pojawia się jeszcze jeden period refutacyjny (12), niejako w odpowiedzi na żywe zapewne podejrzenia co do niebezpieczeństwa grożącego władcy ze strony tak powołanego wojska (podejrzenia, jak się przecież miało okazać, zasadne): 
Non haeret [nie tkwi] ten potus [napój] w sercu u nikogo, aby zgromadzeni cives [obywatele] mieli chęć molliri [czynić], niż się civibus [obywatelom] godzi ${ }^{27}$; tych-ci to Polaków jezdeśmy progenies [potomstwem], których bezpiecznie-to zasypiać królowie mogli; tegośmy orła, póki który pospolitym ruszeniem, nie wojskiem pieniężnem, rozpostrzenione granice tak szyroko skrzydłami okrywa; $\mathrm{z}$ tych-ci to kuźni nosiemy szable u boku,

$z$ któremi i te były,

któremi przodkowie nasi tak siła krwie wytoczyli nieprzyjacielskiej;

haeredit [jest] u nas należące pomazańcom Bożym obseqium [posłuszeństwo],

non exuimus debitum [nie porzucamy należnej] królom, panom naszym, amorem [miłości];

nie masz,

wierze,

nikogo,

któryby miał co non civile [nieobywatelskiego] nie tylko molliri [czynić],

ale nawet meditari [zamyślać]. niepodejmowanie czynów nieobywatelskich

królowie polscy bezpiecznie zasypiali

jesteśmy potomstwem orła chroniącego granice skrzydłami pospolitego ruszenia

te same kuźnie wykuły szable nasze i naszych zwycięskich przodków

jesteśmy posłuszni królom

nie porzucamy należnej im miłości

nikt nie zamyśla nawet niczego nieobywatelskiego

Znajdujemy tu same dobrze znane - chciałoby się rzec: wyświechtane - toposy, nagromadzone (amplifikacyjna congeries) obficie, by liczbą nadrobić ich miałkość dowodową. Wpisane zostały one w ramę zawierającą wyrzeczenie się wszelkiego nieobywatelskiego nie tylko działania, ale nawet myślenia. Jakże tanie były słowa; jakże łatwo elitom państwa przychodził cynizm!

Jako peroratio (periody 13-15) - słowa prawdziwe, mocne perswazyjnie, tyle że znów nic nie wnoszące do postulatu pospolitego ruszenia, bo dotyczące zaległości w żołdzie dla wojska:

Płace wojsku kto by nie wiedział necessitatem [jako konieczność],

musiałby być albo przez sumienia,

abo też rozumu,

abo sine sensu [bez wyczucia],

że nie uczuł mala [zła],

które Rptej recenter [ostatnio] niepłatne wojsko causavit [sprawiło].

Nie chcę tedy tym bawić;

satis est [wystarczy].

Sprawiedliwość każe deservitis [zasłużonym] wypłacać mercedem rat〈am〉 [należny żołd] i świeża malorum memoria suadet [pamięć nieszczęść doradza] podobne in tempore avertere [na czas odwrócić] nieszczęście.

Widać, jak mówca konsekwentnie zawłaszcza niezaprzeczalną wartość argumentacyjną ogromnego zespołu spraw związanych $z$ wojskiem pozostającym miesiącami „w borgowej służbie” i splątuje ją $z$ wątłym dowodowo postulatem pospo- 
litego ruszenia. Czyni to tak zręcznie, że dwa różne problemy wydają się jednym i tym samym.

W zakresie postulatu kolejnego, finansowania wojsk przez województwa i ziemie $^{28}$, pojawia się chwyt ad personam:

[...] nie wiem tam,

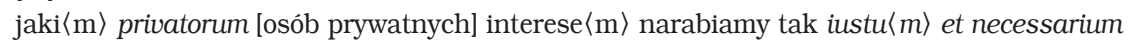

[właściwe i konieczne] wielkiej części Rptej desiderium [pragnienie].

Teraz mam nadzieję,

że tandem aliquido [jednak jakoś] przeważy publiczny interes [...].

Następuje wskazanie postulatu („wojska na województwa podzielić”) i jego uszczegółowienie, przeplatane zwięzła, racjonalną argumentacją. Te dwa periody, 19 i 20, sa przykładem nieozdobnego, „zwykłego” stylu wypowiedzi:

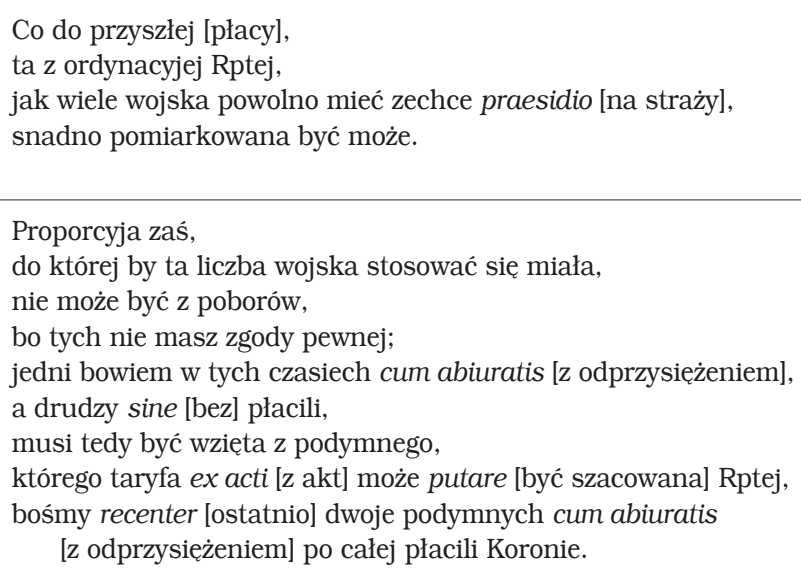

postulat rozsądnego planowania

Kolej na liczne argumentacyjne fructa, wyrażone w podobnie „prostym” stylu (periody 21-26):

\begin{tabular}{|l|l|}
\hline Fructus ingentis [wielką korzyść] z tego podziału mieć będzie Rpta. & zapowiedź wielkich korzyści: \\
\hline $\begin{array}{l}\text { Naprzód komisyje ustana, } \\
\text { źródła wszytkich malorum [nieszczęść], } \\
\text { które }\langle. . .\rangle \text { Rempublicam [Rzeczpospolita]. }\end{array}$ & $\begin{array}{c}- \text { kres komisji wojskowych, } \\
\text { źródła zła }\end{array}$ \\
\hline $\begin{array}{l}\text { Difidencyjej ubędzie, } \\
\text { bo non haeredit opinio in cordibus civium [uprzedzenie nie zachowuje } \\
\text { się w sercach obywateli]. }\end{array}$ & $\begin{array}{c}\text { - kres powszechnej } \\
\text { podejrzliwości }\end{array}$ \\
\hline
\end{tabular}




\begin{tabular}{|c|c|}
\hline $\begin{array}{l}\text { Ja, } \\
\text { przyznam się, } \\
\text { i sam tak wierzę, } \\
\text { że płaca przez komisyje immensa [ogromne] prywatnym przynosi } \\
\quad\langle\ldots\rangle \text { damna [szkody]. }\end{array}$ & - komisje źródłem zła \\
\hline $\begin{array}{l}\text { Wojsko nie pójdzie nigdy w bunt, } \\
\text { bodaj to, } \\
\text { że kiedykolwiek województwo albo ziemia nie zapłaci ex nunc [od } \\
\quad \text { teraz], } \\
\text { przecie trzecie i dziesiąte zapłaci, } \\
\text { i okazyjej do buntów nie będzie. }\end{array}$ & $\begin{array}{l}\text { - kres buntów dzięki } \\
\text { równomierności } \\
\text { wpływów }\end{array}$ \\
\hline $\begin{array}{l}\text { Wojsko będzie lepsze takież, } \\
\text { ale synowie szlacheccy zaciagać się będa, } \\
\text { kiedy tylko będzie certitudo [pewność] płacy, } \\
\text { [...]. }\end{array}$ & $\begin{array}{l}\text { - lepsza jakość wojska } \\
\text { przy pewności wypłaty } \\
\text { żołdu }\end{array}$ \\
\hline
\end{tabular}

Segment ostatni, dotyczacy reform waluty i działalności mennic, zawierał program podwyższenia kursu monety srebrnej. Byłby to, jak uczy teoria ekonomii, środek dobry (nie opłaciłoby się bowiem wywożenie srebrnych monet za granicę), lecz jedynie wtedy, gdyby stał się elementem całego pakietu reform monetarno-skarbowych. Na to nie było szans, ale też ludzie znajdujący się u szczytów władzy powierzchownie tylko rozumieli problem ${ }^{29}$. Ponieważ postulat cieszył się powszechnym poparciem, opatrzony został argumentacją wolną od wysiłków erystycznych, operujacca tymże samym stylem nieozdobnym, „prostym” (periody 29-33):

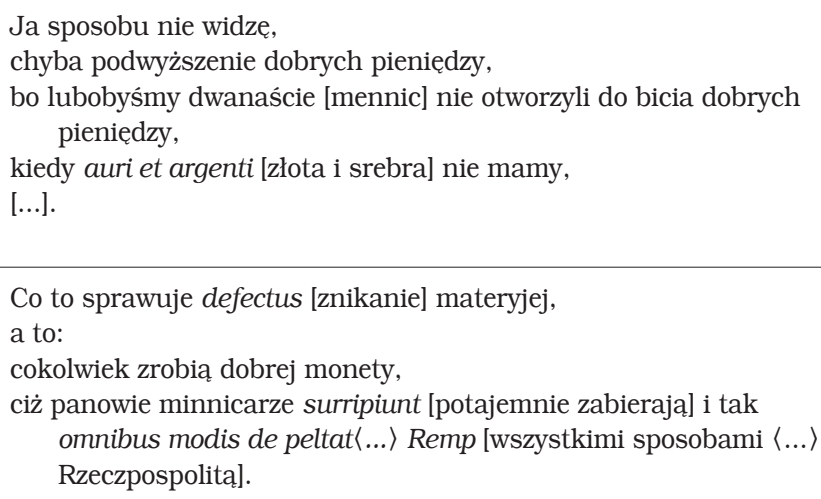

postulat

brak kruszcu

wywożenie srebrnych monet przez mincerzy

Świadomość zła, jakie wyrządzał gospodarce i ludziom „zepsuty” pieniądz, była powszechna i wyrażana przez wszystkie środowiska. Jednak reforma monetarna nie została przeprowadzona nie tylko za Jana Kazimierza, ale też ani za Wiśniowieckiego, ani za Sobieskiego. Okazało się to skomplikowane, a przy tym zabrakło w Polsce ludzi o szerokich horyzontach ekonomicznych (typu Colberta), zdolnych do pokierowania całą polityką skarbowa państwa. Dramat związany z galopującą inflacją stanowił tylko jeden z przejawów braku mądrej polityki ekonomicznej, gdy malało znaczenie podskarbiego i centralnego skarbu, przy jednoczesnej długotrwałej depresji w rolnictwie, 


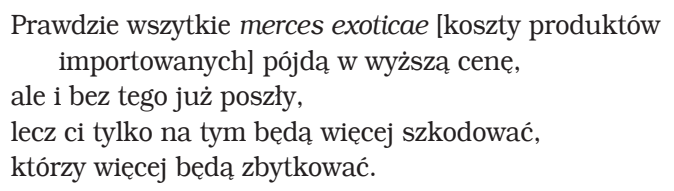

\section{Zróżnicowanie wewnętrzne wotum}

Widoczna jest niejednorodność stylistyczna poszczególnych segmentów. Układają się one - jeśli rozpatrywać stopień nasycenia erystyką, ale też staranność konstrukcyjną, co idzie w parze - w trzy grupy. Najsilniej zretoryzowane sa, jak można było zauważyć, segmenty środkowe, II i III (poświęcone sprawie Lubomirskiego i pospolitemu ruszeniu), natomiast najprostszą argumentacją operują dwie ostatnie cząstki (w sprawie podziału wojsk na województwa i reformy menniczej). Segment I, dotyczący rokowań z Moskwa, lokuje się na tej skali pośrodku, ponieważ, z jednej strony, dowody zaczerpnięte tu zostały $z$ bezpośredniego otoczenia politycznego, sa proste i brzmia jako oczywiste, ale - $z$ drugiej strony - podał je mówca $w$ sposób dość wyszukany i przemyślany.

O ile nietrudne było opisywanie narzędzi zastosowanych we fragmentach zretoryzowanych, o tyle wyzwaniem jest próba określenia znamion stylu umownie nazywanego tu „prostym”.

Na plan pierwszy wysuwają się użyte argumenty - silne swą faktyczną rzeczowością (brak jednolitości w ustaleniu podstawy podatkowej, gdy jedni szacują ją po odprzysiężeniu, a inni bez niego ${ }^{30}$; wypływ srebrnych monet za granice), niepodważalnością ekonomiczną według ówczesnej wiedzy (równomierność wpływów przy rozłożeniu ryzyka na poszczególne ziemie; brak kruszcu w kraju) bądź prawdziwością socjologiczną (uczynienie wypłat dla wojska jawnymi usunie podejrzliwość społeczną; pewność żołdu przyciagnie synów szlacheckich; działalność mennic opleciona jest siecia korupcji). Takie fakty przemawiały same za siebie i nie trzeba było ich amplifikować. Stąd brak zabiegów erystycznych, brak figur retorycznych (i to nie tylko figur słów, bo tych prawie nie znajdziemy również we fragmentach zretoryzowanych, ale nawet figur myśli). Perswazja ta wolna jest też od metaforyki.

ujemnym bilansie handlowym i wzroście znaczenia sąsiadów. Duży wysiłek podatkowy społeczeństwa zmarnowany został przez niesprawny aparat władzy. Zob. ibidem, s. 501-515. 
Druga znamienna cecha fragmentów w stylu „prostym” to względna krótkość odcinków wypowiedzi zamkniętych kropką, niosacych pewną skończoną myśl. Jeśli w całym wotum średnia liczba cząsteczek wewnętrznych, zwanych tu umownie kolonami, przypadających na jeden period argumentacyjny zretoryzowany wynosi prawie 12, to w wypowiedziach zaliczonych do „Zwykłych” - nieco ponad 6. Ograniczenie długości zdania właściwe jest odmianie potocznej języka ${ }^{31}$.

Także ukształtowanie składniowe periodów w stylu „prostym” jest niewyszukane. Te najkrótsze, zawierające dwa, trzy kolony, są najczęściej zdaniami złożonymi podrzędnie, jednokrotnie: przydawkowymi, skutkowymi, dopełnieniowymi. Dłuższe zaś stanowią mieszankę parataksy i hipotaksy, czego przykładem jest cytowany tu period 32 o towarach luksusowych. Wypowiedź następna natomiast, przywołująca skargę mincerza Tymfa (33) - to przejaw uderzającej nieporadności składniowej przy próbie zreferowania przytoczeń cudzych wypowiedzi (nieporadności, dodajmy, nie wykraczającej jednak poza granice poprawności). Widać, z jakim trudem dochodził język polski do dzisiejszej precyzji składniowej stylu średniego, jak trudne było oderwanie się od klasycznego wzorca periodu. Należy wszakże stwierdzić, że poza krótkością zdań nie znajdujemy innych wyrazistych znamion potoczności: przewagi parataksy, luźnych połączeń składniowych, naruszania ciagłości związków bezpośrednich, nadmiaru partykuł czy zaimków wkazujących. Nie obserwujemy takich cech stylu potocznego, jak spontaniczność i niedookreśloność, a ekspresywność, charakterystyczna też przecież dla prozy retorycznej, i formuliczność ${ }^{32}$ - występują w niewielkim zakresie.

Zgodnie $z$ obecnym stanem badań należałoby więc potraktować ów styl, roboczo zwany „prostym”, jako publicystyczną odmianę podtypu oficjalnego mówionego.

Zrozumiała jest, jak można sądzić, przyczyna odmienności cząstek środkowych (dotyczyły problemów trudnych, przy których mówca oczekiwał nieprzychylności monarchy i stronnictwa regalistycznego, a jednocześnie nie chciał palić za sobą mostów) od końcowych, nie wymagających szczególnej perswazji. Segment I merytorycznie nie mieści się w sposób czysty w żadnej z dwóch grup: nie sprzeciwiał się wprost woli króla, ale spełnienie postulatu przedłużyłoby obrady (co już byłoby nie po myśli władcy, budowałoby wszakże wizerunek mówcy jako trybuna ludowego). Może też to, iż zagadnienie rokowań przedstawione zostało w pierwszej kolejności, wpłynęło na jego staranniejszą obudowę retoryczną. Zauważyć przy tym warto, że obie sprawy problematyczne wciśnięte są w środek wotum. Nie wyeksponował ich mówca na początku, a po nich umieścił kolejne jeszcze segmenty. Pozbawiając najistotniejsze komunikaty atrakcyjnego usytuowania, chował je poniekąd, osłabiał ich wymowę. Nie pragnął zapewne stawiania sprawy na ostrzu noża.

\section{Prooemium czy insinuatio}

Aby wyraźnie dostrzec rozwarstwienie stylistyczne wotum Grzymułtowskiego, warto na koniec rzucić okiem na dwa pierwsze periody, budujące wstęp, a stanowiące najczystszy przejaw odmiany oratorskiej popisowej: 
A kiedyżby, jeżeli nie teraz,

Patris Patriae [Ojca Ojczyzny] imieniem compellare [nazywać] WKMść PNMego,

kiedy $^{33}$

(credentissima [najprawdziwsze] tylko przypomnię WKMci beneficia [dobrodziejstwa])

zleczywszy tak ciężką wszytkim stanom zadaną od wojska związanego fortę,

niezłeż zdrowie WKMci,

cum gregariis [z żołnierzami] pracując in Scillas et Charibdas [między Scyllą a Charybda],

gdzie od dawnych wieków porządkiem dobrem,

iż pod żadnym polskim monarchą końskie nie deptało kopyto drogi,

albo ex cubilibus [z legowisk],

dzikiego

i którego krwie ludzkiej 〈...〉 libido [żądza] nasycić [się] nie może,

nieprzyjaciela expugnare [wygnać],

albo też łaskawością evincere [zmiękczyć],

kiedy po tych trudach nic albo mało barzo wypocząwszy,

tak ciężką sześćniedzielnego sejmu,

malo fato [złym losem] ojczyzny naszej starganego,

poniosłeś fatygę,

kiedy jak znowu bez wytchnienia,

bez respektu na zdrowie i wczasy królewskie,

w też ci zaś zaprzęgasz się prace

i nas do tej wolnej zwołujesz gromady,

abyśmy societatis laboribus [wysiłkami wspólnoty]

zawsze doroczne

raz te nasze wszytkich calamitatum in saltis avertere [nieszczęścia

w knieje wygnać] mogli.

In hocque tedy laborum cursu [w tym biegu prac] słusznie,

WKMć Panie nasz Mciwy,

nie tylko dominum confitemur [wyznajemy jako pana],

ale patrem veneramur [czcimy jako ojca],

niech Bóg hojnym błogosławięstwem długim i szczęśliwym

nadgradza WKMci panowanie,

niech powierzony od Boga WKMci narody winnym,

a wolnemu narodowi niesromotnym,

wypłacają trybutem,

to jest dobroczynności przyznaniem. pytanie retoryczne

rytmizujace powtórzenia

figura kompozycyjna

percursio

wyjątkowość sytuacji

topos okrutnego wroga

argumentum ad misericordiam

topos fatum

argumentum ad misericordiam

Podstawową rolą exordium jest właściwe przygotowanie odbiorcy, a więc bezpośrednio - monarchy, a pośrednio także senatorów i Izby Poselskiej. Wstęp pojawia się tu, jak się wydaje, w odmianie tradycyjnej, zwanej prooemium, w której jawnie i wprost dąży się do pozyskania życzliwości słuchacza, do ułatwienia mu 
zrozumienia sprawy lub do przyciagnięcia jego uwagi. W słowach kasztelana poznańskiego skierowanych do króla zauważamy pierwszą z owych trzech możliwych formuł: benevolentum parare. Narzędzia użyte w celu pozyskania życzliwości tego głównego słuchacza to wyliczenie niezaprzeczalnych zasług monarchy: nadzwyczajnego osobistego męstwa wojennego, elastyczności w postępowaniu wobec wroga, poświęcania swego zdrowia, a wreszcie cierpliwości i wytrwałości w demokratycznej procedurze sejmowania. Jako słuszny wniosek tak nakreślonego portretu władcy wyłania się wyznanie czci, złożone przez mówce jako reprezentanta „wolnego narodu". Grzymułtowski stosuje konsekwentnie formę pierwszej osoby liczby mnogiej, brzmiąca tym silniej, że w wyrazistych końcówkach łacińskich: „,nie tylko dominum confitemur, ale patrem veneramur". W ślad za tym ida życzenia błogosławieństwa i szczęśliwego panowania jako Boskiej nagrody, a „przyznania dobroczynności” jako należnej, jednocześnie zaś nie naruszającej honoru szlacheckiego, daniny od społeczeństwa.

Stwierdzić należy, że wstęp ten jest konstrukcją udaną, gdyż odzwierciedla, przynajmniej na pozór, pozytywne emocje społeczne wyzwalane przez osobę Jana Kazimierza, nie popadając w przesadę serwilizmu. Nie zastosował mówca pochlebstw, które by jawnie kontrastowały z rzeczywista opinią, jaką cieszył się władca. Powszechnie ceniono bowiem wysoko męstwo króla na polu bitwy, owo wytrwałe pozostawanie „cum gregariis”, a także jego talent taktyczny. Jednocześnie jednak Grzymułtowski nie zapomina, że słuchaja go również senatorowie i szlachta reprezentujący stronnictwo Lubomirskiego. Stąd argumenty ad populum: akcentowanie „wolnej gromady”, „dorocznych wspólnych trudów” i „wolnego narodu” zachowującego „niesromotność” przy chwaleniu władcy. Gdybyśmy nie znali okoliczności politycznych towarzyszących sejmowi w r. 1665, budziłyby zastanowienie ta samodyscyplina przy zabiegach dążących do captatio benevolentiae (zyskania przychylności), umiar i ostrożność w szafowaniu pochwałami. Dostajemy portret władcy na pozór piękny i malowany szacunkiem, ale gotowy w każdej chwili do poddania się cenzurze, do reakcji na swoiste „sprawdzam” ze strony słuchaczy.

$\mathrm{W}$ takim razie konstrukcja, która wydawała się prooemium, przedstawia się jednak jako wstęp insynuacyjny, mający przeniknąć do słuchacza nie bezpośrednio i jawnie (jak prooemium), lecz poprzez utajenie i obejście. Teoretycy zalecaja ten rodzaj wstępu, gdy mówca zabiera głos w niegodziwej sprawie, na nieprzychylnym gruncie lub przy znużeniu publiczności. Zabieg ów to próba wpłynięcia na podświadomość słuchaczy, by w trudnej sytuacji zdobyć sympatię ${ }^{34}$. Zachodzą tu prawdopodobnie dwie pierwsze okoliczności.

Gdy do analizy wstępu dołączymy wiedzę o uwarunkowaniach historycznych towarzyszących sesji parlamentu w r. 1665, a więc narastającą w społeczeństwie niechęć do władcy, w nim samym zaś pewnego rodzaju wypalenie i znużenie trudami królowania, obopólne szukanie popleczników po obcych dworach, nieufność wszystkich wobec wszystkich i rozpalający się właśnie płomień wojny domowej odkryjemy w pochwale Jana Kazimierza złowrogą nutę hipokryzji. Oto monarchę „wyznaje jako pana i czci jako ojca” - senator, który najdalej za dwa miesiące zacznie

34 Zob. H. La u sberg, Retoryka literacka. Podstawy wiedzy o literaturze. Przekł., oprac., wstęp A. Gorzkow ski. Bydgoszcz 2002, s. 170-171, § 280-281. 
zwoływać przeciwko niemu pospolite ruszenie. Dodajmy też, że tą samą hipokryzją wypełnił Grzymułtowski portret króla mądrego jak Salomon w segmencie II (period 7).

Mamy oto w jednej, nieszczególnie długiej, oracji pełną paletę odmian stylu: od całkowicie podporządkowanego normom retoryki, przemyślnego i ozdobnego wstępu, poprzez mocne argumentacyjnie, nasycone erystyka segmenty II i III oraz porządnie ułożony, choć argumentacyjnie prosty segment I, aż do segmentów IV i V - zwyczajnych, zrzekających się pomocy retoryki, wręcz byle jakich.

Zjawisko rodzenia się stylu średniego w wypowiedzi oficjalnej, szukania „złotego środka” między Scylla zdegenerowanej retoryczności a Charybdą potoczności, godne jest dalszego badania, opartego na szerszym materiale oracji programowych z drugiej połowy XVII wieku.

Abstract

KRYSTYNA PŁACHCIŃSKA University of Łódź

\section{SEYM ORATIONS FROM THE TIMES OF JOHN CASIMIR VASA AT THE STYLISTIC CROSS- ROADS (THE CASE OF KRZYSZTOF GRZYMUŁTOWSKI'S 1665 VOTE)}

The Castellan of Poznań, Krzysztof Grzymułtowski's speech delivered in the Seym in 1665 is an example of inner differentiation in a statement's style. Besides the "high" style, rich in the applications of rhetorical tools, there are some parts in the "average" style and look almost like a colloquial language.

Parliamentary speeches of the second half of $17^{\text {th }}$ century are the excellent base for studies of then forming "average-official" style of statement. 